\title{
Preliminary observation on the sustainability of white sardine, Escualosa thoracata (Valenciennes, 1847), exploited from the central west coast of India
}

Udai R. Gurjar 1,2, Suman Takar1,3, Milind S. Sawant², Ravindra A. Pawar², Vivek H. Nirmale², Anil S. Pawase², Sushanta K. Chakraborty ${ }^{1}$, Karan K. Ramteke ${ }^{1}$ and Tarachand Kumawat ${ }^{1,4^{*}}$ (i)

\begin{abstract}
Background: The present study assessed the growth and mortality parameters of the white sardine, Escualosa thoracata which is having high local demand. The white sardine gained importance due to its taste, and high demand in domestic markets as compared to the oil sardine necessitated a study on this resource to know the present status of exploitation level along the central west coast of India.

Results: A total of 3026 individuals of different size groups of $E$. thoracata were randomly collected from the Burondi fish landing center of the Ratnagiri district of Maharashtra. The asymptotic length $\left(L_{\infty}\right)$ and growth coefficient (K) were estimated to be $115 \mathrm{~mm}$ and 1.9 year $^{-1}$, respectively, by ELEFAN-I and $135 \mathrm{~mm}$ and 1.2 year $^{-1}$ by the scattergram. The value of $t_{0}$ by von Bertalanffy plot was estimated to be -0.000012 year. The fish attained a length of $65 \mathrm{~mm}, 94 \mathrm{~mm}$, and $114 \mathrm{~mm}$ at the end of 0.5, 1, and 1.5 years of its life, respectively. The instantaneous rate of total mortality $(Z)$, natural mortality $(M)$, and fishing mortality $(F)$ were estimated to be 8.07 year $^{-1}, 2.55$ year $^{-1}$, and 5.52 year $^{-1}$, respectively. The exploitation rate $(U)$ was calculated as 0.65 , and the exploitation ratio $(E)$ was 0.68 .

Conclusion: The growth, mortality, and other population parameters observed in the present study will help to understand the current stock status, which is pointing toward the over-fishing condition ( $\left.E^{>} 0.50\right)$ of the white sardine in the study area. Therefore, the present investigation suggests reducing the fishing pressure on $E$. thoracata along the central west coast of India for the sustainability of the resource.
\end{abstract}

Keywords: Exploitation, Growth, Length-frequency, Mortality, White sardine

\section{Background}

White sardine, Escualosa thoracata (Valenciennes, 1847), supported economically important fishery along the south-west coast of India (Nair, 1952), and it also occurs in swarms on the east coast of India (Mookerjee \&

\footnotetext{
* Correspondence: tarachand.kumawat@icar.gov.in

'ICAR-Central Institute of Fisheries Education, Mumbai, Maharashtra 400 061, India

${ }^{4}$ ICAR-Central Marine Fisheries Research Institute, Veraval, Gujarat 362 269,

India

Full list of author information is available at the end of the article
}

Bhattacharya, 1950). This species was recorded from India, Pakistan, Sri Lanka, Myanmar, Malaya, Malay Archipelago, China, eastward to the Philippines, Papua New Guinea, and Australia (Krishnan \& Mishra, 2004; Misra, 1947). It is a shoaling clupeid, inhabiting most of the shallow coastal waters of India. White sardines form a seasonal fishery throughout their range of distribution along the Indian coast (Abdussamad et al., 2018). The fishery of $E$. thoracata has gained importance in recent years due to its huge demand in domestic markets (Gurjar et al., 2017). Increasing demand for seafood and 
advancement in harvest technology have led to the overexploitation of marine resources (Takar \& Gurjar, 2020). The total marine fish catch recorded during 2017 from Maharashtra was 3.81 lakh tons, with the pelagic group contributing 39\% of the catch (CMFRI, 2018). This fish was captured using gill nets and cast nets operated in shallow creeks, supporting a common fishery along the Harnai-Dabhol coast of Ratnagiri, Maharashtra (Gurjar, Sawant, Pawar, Nirmale, \& Pawase, 2018).

Knowledge of length-weight, growth, and mortality parameters is essential for understanding the population dynamics of different species (Gosavi, Kharat, Kumkar, \& Tapkir, 2019; Gurjar et al., 2017; Kende et al., 2020). Several approaches were generally used to determine the age and growth of the aquatic species, such as lengthfrequency analysis, tagging and recapture experiments, and observations of the mark on the various hard body parts like scales, otoliths, spines, and vertebrates (Stéquert, Panfili, \& Dean, 1996). The population characteristics of $E$. thoracata were recorded from the north-west coast of India (Prajapat, 2015; Rahangdale, Chakraborty, Jaiswar, Shenoy, \& Raje, 2016; Raje, Deshmukh, \& Thakurdas, 1994) and the south-west coast of India (Abdussamad et al., 2018). But there is no report related to population dynamics and stock status of white sardine resources from the Ratnagiri, central west coast of India. As the distribution of white sardine along Ratnagiri is restricted to only along the Harnai-Dabhol coast of Ratnagiri, the present level of commercial exploitation, highly natural of the seasonal fishery, and its high local demand required an in-depth study with respect to the fishery and stock status. Therefore, this study was designed to assess the growth and mortality parameters and know the present status of exploitation level of $E$. thoracata along the Ratnagiri, central west coast of India.

\section{Methods}

\section{Sample collection and study area}

The specimens of different size groups of $E$. thoracata were randomly collected twice in a month from the Burondi (Lat $17^{\circ} 42^{\prime} 55.5^{\prime \prime} \mathrm{N}$ and Long $73^{\circ} 07^{\prime} 81.4^{\prime \prime} \mathrm{E}$ ) fish landing center in the Ratnagiri district of Maharashtra during the period from February 2015 to January 2016.

\section{Estimation of age and growth parameters}

The total lengths of all samples (3026 individuals) were measured for the estimation of length-frequency distribution. Length-frequency data were grouped into $5-\mathrm{mm}$ class intervals and raised for the day and subsequently for the month as followed by Sekharan (1962). The initial estimate of growth parameters $\left(L_{\infty}\right.$ and $\left.K\right)$ was made using the scatter-diagram technique (Devaraj, 1983). In this method, the modal lengths in the length-frequency data are first plotted in the form of a scatter diagram against coordinates of length starting from 0 onward on the $\mathrm{Y}$-axis and time in months on the $\mathrm{X}$-axis. An eyefitted line indicates the trend in the progression of the modes through time. The fitted line was extrapolated in a freehand manner with reference to the intermodal slopes so that it intersects the time axis, indicating the time of brood release and the growth of the brood since its origin through successive months. The mean length read at monthly intervals was obtained by taking an average of eye fitted line, which was used for the calculation of $L_{\infty}$ and $K$ employing von Bertalanffy's equation (1934):

$$
\mathrm{Lt}=L_{\infty}\left(1-e^{-k\left(t-t_{0}\right)}\right)
$$

Applying standard regression analysis, the $a$ and $b$ values of $L_{\mathrm{t}}$ against $L_{\mathrm{t}+1}$ in the data were obtained. From this, asymptotic length $\left(L_{\infty}\right)$ was calculated as:

$$
L_{\infty}=a / 1-b \text { and growth coefficient } k=-\ln b
$$

The growth parameters $\left(L_{\infty}\right.$ and $\left.K\right)$ were also estimated by ELEFAN-I, using length-frequency by employing the FiSAT program. Length at age data was produced by using mean length obtained in scatterdiagram technique and employing inverse von Bertalanffy growth formula (VBGF) (von Bertalanffy, 1938) as:

$$
t=t_{0}-(1 / K) * \ln \left(1-L t / L_{\infty}\right)
$$

Hypothetical age at which length is zero $\left(t_{0}\right)$ was estimated using von Bertalanffy (1934) plot. The growth performance index, phi prime $\left(\phi^{\prime}\right)$, was estimated by following Munro and Pauly (1983), given as:

$$
\phi^{\prime}=2 \times \log \left(L_{\infty}\right)+\log (K)
$$

\section{Estimation of mortality parameters and exploitation status}

The total instantaneous mortality $(Z)$ was calculated by following the length-converted catch curve (Pauly, 1983, 1984) and cumulative catch curve method (Jones \& Van Zalinge, 1981) by employing the FiSAT program. The natural mortality coefficient $(M)$ was estimated by using the method of Pauly (1980) and Cushing (1968). The fishing mortality $(F)$ was calculated using the relationship, $F=Z-M$. The exploitation ratio $(E)$ was estimated by the formula given by Ricker (1975), $E=F / Z$, and exploitation rate $(U)$ was calculated by using formula $U=$ $(F / Z)^{*}\left(1-e^{-z}\right)$ given by Beverton and Holt (1957).

\section{Results}

The white sardine, E. thoracata, is locally (along the central-west coast of India) known as "Bhiljee" due to its silvery-white shiny appearance. The small fishing boats 
were engaged for fishing of $E$. thoracata in the nearshore areas along the Ratnagiri coast at a depth of 8-10 m using a small meshed (20-22-mm mesh size) drift gill net locally called Bhiljee jaal or Bhushi. For the present study, a total of 3026 fish specimens of E. thoracata were used.

\section{Length-frequency analysis}

During the study period, the randomly collected samples fell in the length range of $69-110 \mathrm{~mm}$ (total length), which were mainly dominated between the size groups of 86-90 to 101-105 mm caught from 60 to 70 small fishing boats. A progressive increase in the dominant size group in catch was observed from February 2015 to January 2016 (Fig. 1).

\section{Estimation of growth parameters and growth performance index}

The scatter-diagram technique yielded five curves of almost identical shape, and the growth was observed at monthly intervals. The modal lengths observed at different months are presented in Fig. 2 where the growth parameters $\left(L_{\infty}\right.$ and $\left.K\right)$ were estimated at $135 \mathrm{~mm}$ and 1.2 year $^{-1}$ respectively. The $L_{\infty}$ and $K$ values estimated by ELEFAN-I were recorded as $115 \mathrm{~mm}$ and 1.9 year $^{-1}$ respectively for $E$. thoracata, and these values were considered for further calculations to estimate population parameters. The value of hypothetical age at length zero $\left(t_{0}\right)$ was calculated as -0.000012 year by von Bertalanffy's plot. The growth performance index or phi prime $\left(\phi^{\prime}\right)$ for $E$. thoracata recorded from Ratnagiri waters was 2.40.

\section{Estimation of length at age}

Precise information on the age of fish at a particular length is an essential pre-requisite for getting accurate information on recruitment, growth, and mortality parameters of fishes for stock assessment. The mean length estimated by the scatter-diagram technique was

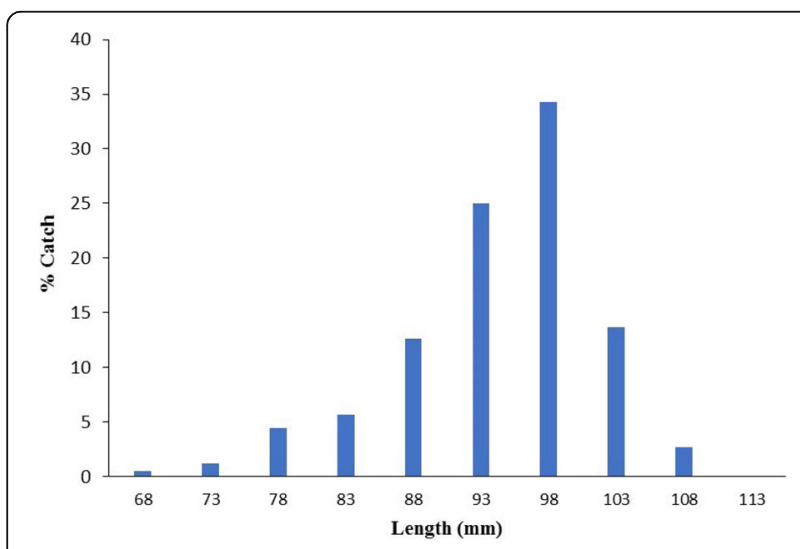

Fig. 1 Percentage length composition of the catch of E. thoracata

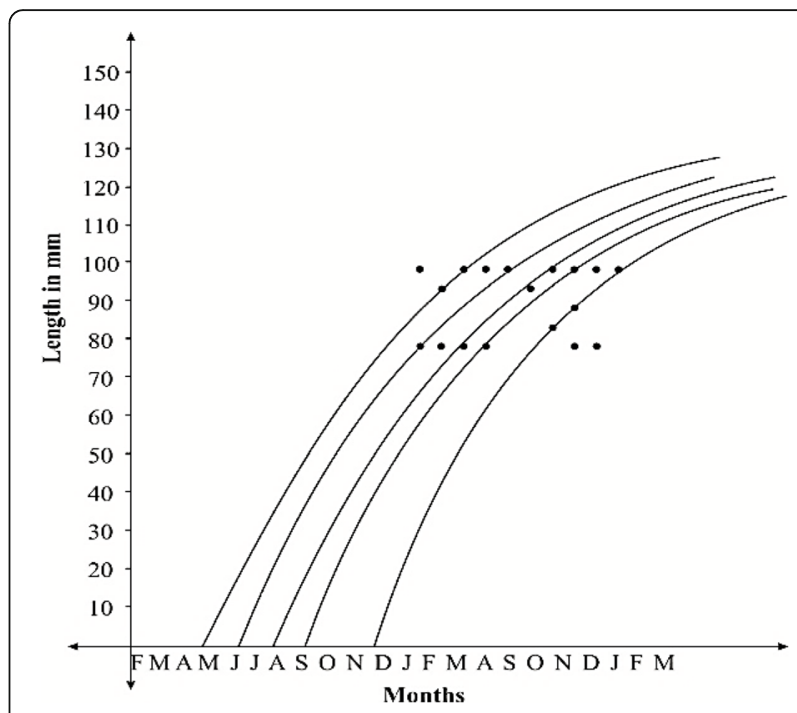

Fig. 2 Model progression analysis of length frequencies observed in E. thoracata by scatter diagram technique

considered for the calculation of age attained using the VBGF in this study. It was recorded that $E$. thoracata attains a length of $65 \mathrm{~mm}, 94 \mathrm{~mm}$, and $114 \mathrm{~mm}$ at the end of $0.5,1$, and 1.5 years of its life, respectively. The maximum size recorded during the study period was $110 \mathrm{~mm}$, and the corresponding age was calculated at 1.40 years (Fig. 3).

Estimation of mortality parameters and exploitation ratio Mortality parameters are a measure of delineating the rate at which fish vanish from a population and are crucial parameters in framing sustainable fishing rules and regulations (Ogle, 2016). The value of $Z$ estimated by the length converted catch curve method (Fig. 4) and the cumulative catch curve method (Fig. 5) was found to be 8.07 year $^{-1}$ and 6.22 year $^{-1}$, respectively. The natural mortality coefficient $(M)$ was estimated to be 1.80 year $^{-1}$ and 2.55 year $^{-1}$ by Pauly's and Cushing's formula,

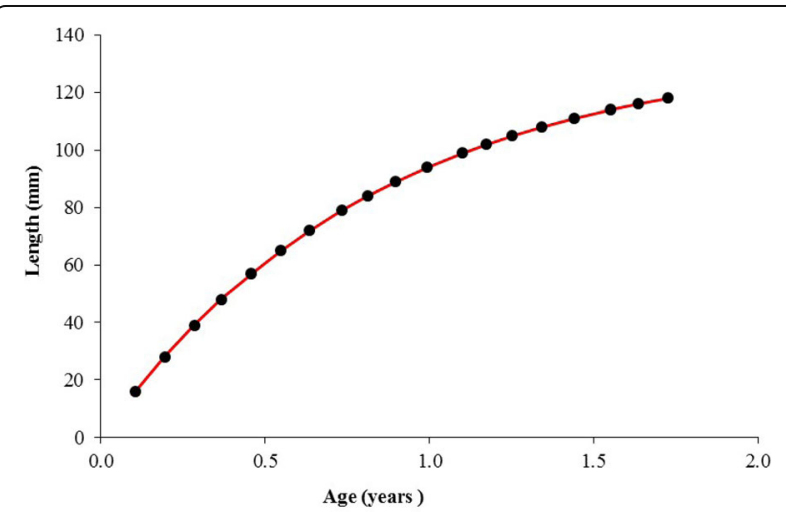

Fig. 3 VBGF growth curve for estimation of length at age of E. thoracata 


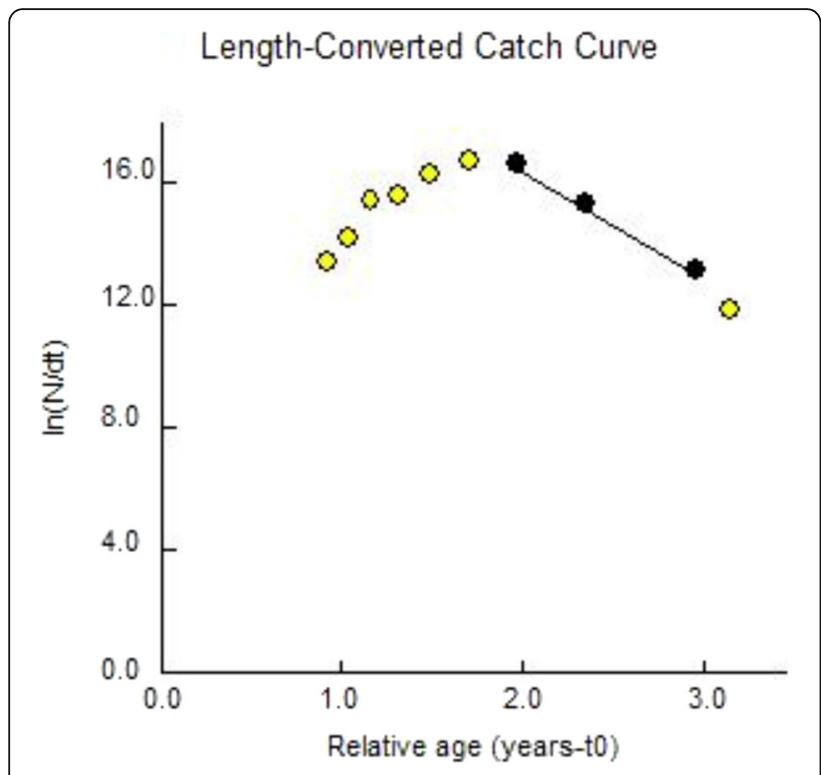

Fig. 4 Length converted catch curve for estimation of total mortality coefficient for E. thoracata

respectively. The annual fishing mortality coefficient $(F)$ was estimated by subtracting natural mortality $(M)$ from the total mortality coefficient $(Z)$, which gives the value of 5.52 year $^{-1}$. In the present study, $M / K$ and $Z / K$ values were calculated as 1.34 and 4.25 , respectively, for $E$. thoracata. In the present study, the observed value of exploitation rate $(U)$ was 0.65 , and the exploitation ratio (E) was 0.68 for E. thoracata harvested from Ratnagiri waters.

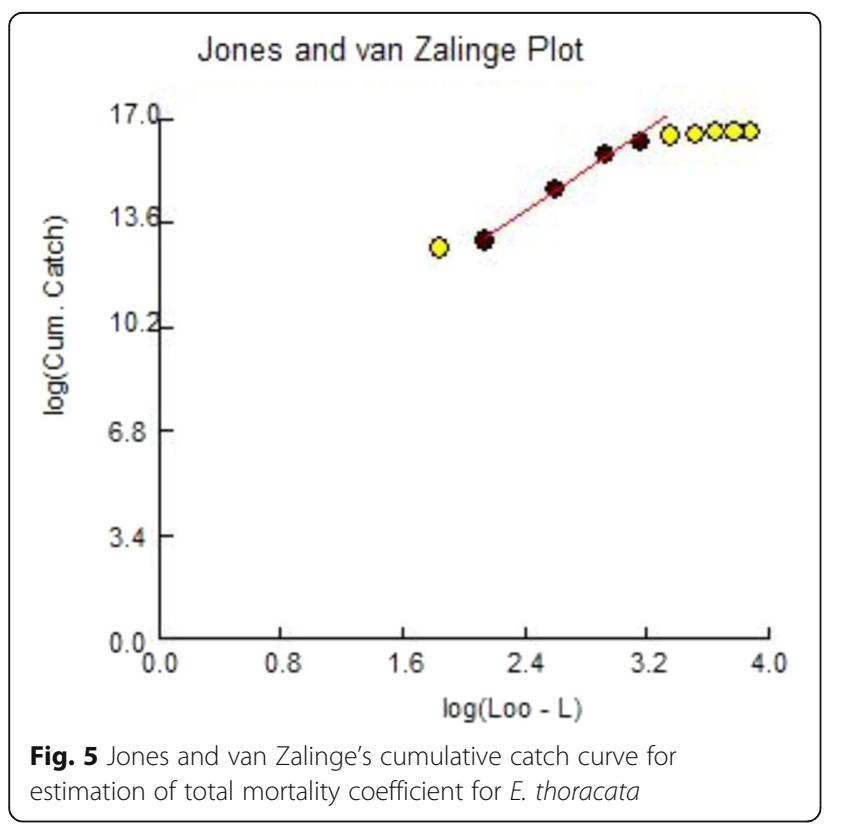

\section{Discussion}

\section{Length-frequency analysis}

Commonly, the size structure of one fish species can be characterized by the length-frequency distribution (Taiwo, 2010). The total length ranges observed in the present study are comparable to those earlier reported from different locations presented in Table 1. Along the Ratnagiri coast, the smallest size of fish recorded was 69 $\mathrm{mm}$, which is comparatively larger than reported by others. It might be due to drift gillnet (mesh size 20-22 $\mathrm{mm}$ ) was used to catch white sardine along the Ratnagiri coast, so small-sized fishes escaped from the large mesh size of the net. Nair (1952) has reported a unimodal $(10.5 \mathrm{~cm})$ feature of length-frequency distribution of fishery, accounting for almost one-third of the catch emphasizing the dominance of a single age group in the catch (Raje et al., 1994). The dominance of the singlelength group was observed in the present investigation with $98 \mathrm{~mm}$ (mid-class length), accounting for more than one-third of the total annual catch. While comparatively, the dominance of the length group of $77 \mathrm{~mm}$ (mid-class length) was recorded from Mumbai waters (Rahangdale et al., 2016). The differences in the dominance of the size group might be due to the methods of exploitation heterogeneity of habitat and diversity of genetics (Parra, Almodóvar, Nicola, \& Elvira, 2009).

\section{Estimation of growth parameters and growth performance index}

The $L_{\infty}$ and $K$ values estimated by ELEFAN-I were recorded as $115 \mathrm{~mm}$ and 1.9 year $^{-1}$ respectively for $E$. thoracata, and these values were considered for further calculations to estimate population parameters. The $L_{\infty}$ and $K$ values were comparatively lower than the earlier described values by Nabi et al. (2009); Rahangdale et al. (2016); and Abdussamad et al. (2018) (Table 2). The value of hypothetical age at length zero $\left(t_{0}\right)$ was calculated as -0.000012 year by von Bertalanffy's plot. The theoretical age at length zero often has a small positive or, more usually, a small negative value (King, 1995). The values of $t_{0}$ in the present study corroborate this fact. The growth performance index can be used as a reliable index for the assessed parameters of growth as the value of phi prime $\left(\phi^{\prime}\right)$ for the same species and genera are similar. The growth performance index or phi prime $\left(\phi^{\prime}\right)$ for E. thoracata recorded from Ratnagiri waters was 2.40. The observed growth performance index value was high; therefore, it is an interesting remark because phi prime $\left(\phi^{\prime}\right)$ is known to be a highly species-specific parameter with their values being similar within related taxa or groups (Prasad, Ali, Harikrishnan, \& Raghavan, 2012). The current estimate of phi prime was similar to Nabi et al. (2009), Prajapat (2015), Rahangdale et al. (2016), 
Table 1 Size range of $E$. thoracata from different localities

\begin{tabular}{lll}
\hline Size range $(\mathbf{m m})$ & Area & Authors \\
\hline $60-120$ & Madras & Devanesan and John (1941) \\
$25-72$ & Mumbai & Mookerjee and Bhattacharya (1950) \\
$100-110$ & Malabar coast & Nair (1952) \\
$41-105$ & Mumbai & Raje et al. (1994) \\
$25-119$ & Bangladesh & Nabi, Hoque, and Rahman (2009) \\
$49-109$ & Mumbai & Shabir, Thomas, Chakraborty, and Jaiswar (2014) \\
$60-117$ & Goa & Prajapat (2015) \\
$22-111$ & Mumbai & Rahangdale et al. (2016) \\
$36-102$ & Kerala & Abdussamad et al. (2018) \\
$69-110$ & Ratnagiri & Present study
\end{tabular}

Raje et al. (1994), and Abdussamad et al. (2018), which confirm the accuracy of the estimates (Table 2).

\section{Estimation of length at age}

In the earlier studies, Mookerjee and Bhattacharya (1950) recorded the mean length $25.5 \mathrm{~mm}$ in the month of April and reached about $72 \mathrm{~mm}$ in October, which measured an average growth of $7.8 \mathrm{~mm}$ per month. Nair (1952) estimated that the first-year growth of this species was $100-110 \mathrm{~mm}$ and stated that the average life span of this species is below 1 year, and very few survived beyond this age. He also noted that the size class which dominated the fishery every successive year was the stock recruited during the previous spawning season. Raje et al. (1994) have estimated the length at 0.5 and 1.0 year age as 65.3 and $91.8 \mathrm{~mm}$ by employing the VBGF. The maximum length of fish recorded was 105 $\mathrm{mm}$, from which the calculated age was 1.7 years.

The maximum size was recorded $110 \mathrm{~mm}$ in the present investigation, with a calculated age of 1.40 years. Similarly, Rahangdale et al. (2016) recorded the maximum length of $111 \mathrm{~mm}$ with an estimated age of 1.42 years. As per VBGF, they found that the fish attained $72.77 \mathrm{~mm}$ size in 6 months and $100.79 \mathrm{~mm}$ in 1 year. Prajapat (2015) observed the growth of the white sardine at 6 months and 1 year, 86 and $114.5 \mathrm{~mm}$, respectively, and the largest specimen obtained during the study period was $117 \mathrm{~mm}$ with an estimated age of 1.08 years.
This was mainly because of the higher values of $K$, which resulted in faster growth of the species. Abdussamad et al. (2018) have recorded a maximum size of $105 \mathrm{~mm}$ with the length of $50 \mathrm{~mm}, 79 \mathrm{~mm}, 96 \mathrm{~mm}$, and $106 \mathrm{~mm}$ in $3,6,9$, and 12 months, respectively.

\section{Estimation of mortality parameters and exploitation ratio} In the present investigation, fishing mortality recorded nearly two times of its natural mortality indicated a fairly high fishing pressure on this resource along the Ratnagiri coast. Nabi et al. (2009) estimated the total mortality, natural mortality, and fishing mortality 8.08 year $^{-1}$, $2.82 \mathrm{year}^{-1}$, and $5.26 \mathrm{year}^{-1}$, respectively, for $E$. thoracata, which also indicates the high fishing mortality than the natural mortality from Bangladesh waters. The mortality parameters observed in the present study are almost similar to the parameters recorded from Bangladesh, north-west, and south-west coast of India (Table 3).

The information on the mortality rate was important for devising exploitation strategies to harvest and manage the fishery resources at optimal levels. The natural mortality coefficient in fish varies with age and predator abundance (Boiko, 1964; Jones, 1982; Pauly, 1980). It was difficult to estimate the natural mortality in tropical countries as the standard method of $Z$ against efforts does not give a correct estimate of natural mortality as apportioning of the efforts is not possible. Hence,

Table 2 Comparisons of growth parameters for $E$. thoracata from different localities

\begin{tabular}{llllll}
\hline Locality & $\boldsymbol{L}_{\boldsymbol{N}}(\mathbf{c m})$ & $\boldsymbol{K}\left(\mathbf{y e a r}^{-\mathbf{1}}\right)$ & $\boldsymbol{t}_{\boldsymbol{o}}$ (year) & $\boldsymbol{\varphi}^{\prime}$ & Authors \\
\hline Mumbai & 11.0 & 1.80 & - & 2.34 & Raje et al. (1994) \\
Bangladesh & 12.08 & 1.40 & - & $2.31^{\text {a }}$ & Nabi et al. (2009) \\
Goa & 12.95 & 1.16 & -0.00911 & $2.56^{\text {a }}$ & Prajapat (2015) \\
Mumbai & 11.96 & 2.19 & -0.000095 & 2.42 & Rahangdale et al. (2016) \\
Kerala & 11.87 & 1.0 & -0.00261 & $2.49^{\text {a }}$ & Abdussamad et al. (2018) \\
Ratnagiri & 11.4 & -0.000012 & 2.40 & Present study \\
\hline
\end{tabular}

${ }^{a}$ Calculated based on the $L_{\infty}$ and $K$ values reported by original authors 
Table 3 Mortality and exploitation ratio for E. thoracata from different localities

\begin{tabular}{llllll}
\hline Locality & $\boldsymbol{M}$ & $\boldsymbol{F}$ & $\boldsymbol{Z}$ & $\boldsymbol{E}$ & Authors \\
\hline Bangladesh & 2.82 & 5.26 & 8.08 & 0.65 & Nabi et al. (2009) \\
Mumbai & 3.459 & 4.35 & 7.809 & 0.557 & Rahangdale et al. (2016) \\
Kerala & 2.43 & 6.28 & 8.71 & 0.72 & Abdussamad et al. (2018) \\
Ratnagiri & 2.55 & 5.52 & 8.37 & 0.68 & Present study \\
\hline
\end{tabular}

numerous methods have to be tried, and more often, we have to depend on the $M / K$ as an indicator of the accuracy of $M$ and $K$. The $M / K$ ratio of 1.0 to 2.5 indicates correctness in the assessment of the natural mortality coefficient. In the present study, $M / K$ ratio was found to be 1.34, which lies in the range of 1.0 to 2.5 (Beverton \& Holt, 1957), indicating that the estimates were fairly reasonable. A stock is considered mortality-dominated if the $Z / K$ value is equal to more than two and growthdominated if $Z / K$ value is equal to one. Based on this, the existing stock of $E$. thoracata was found to be mortality-dominated as the calculated value of $Z / K$ was 4.25. The optimum $E$ value 0.5 was suggested by Gulland (1971) for overall fisheries management, and in the case of pelagic stocks, 0.4 is recommended (Patterson, 1992). In the present study, the observed exploitation ratio (0.68) was higher than the optimum (0.5), which predicted high fishing pressure on the white sardine stock along the central west coast of India. As similar to the present study, a higher level of exploitation was observed by Nabi et al. (2009), Rahangdale et al. (2016), and Abdussamad et al. (2018) from different geographical areas (Table 3). For stability of the species in the Ratnagiri waters, it is needed to maintain at least $50 \%$ of the spawning stock, and therefore, the current level of exploitation needs to decrease.

\section{Conclusions}

This is the first report on the population characteristics and stock status of E. thoracata from the Ratnagiri, central west coast of India. From this study, it is evident that the stock of E. thoracata is overexploited. $E$. thoracata is a very fast-growing species having an annual $K$ of 1.9 , with a short life span that may be completing its life cycle of about $1.2-1.5$ years. The exploitation ratio $(E)$ was 0.68 , which is very much on the higher side of optimum exploitation $(E=0.5)$; therefore, fishing pressure can be reduced, and regular monitoring of the resource would be required to have a sustainable catch. In all these aspects, the present study would form the basis for the scientific community and conservation decision-makers to manage and reach the sustainable harvest of this resource with optimal exploitation.

\begin{abstract}
Abbreviations
$L_{\infty}$ : Asymptotic length; $K$ : Growth coefficient; Z: Total mortality; M: Natural mortality; F: Fishing mortality; U: Exploitation rate; E: Exploitation ratio; E. thoracata: Escualosa thoracata; $t_{0}$ : Age at length zero; VBGF: von Bertalanffy growth formula; $\varphi^{\prime}$ : Phi prime; FiSAT: FAO-ICLARM Stock Assessment Tools; ELEFAN-I: Electronic Length Frequency Analysis-I
\end{abstract}

\section{Acknowledgements}

The authors are thankful to the Dean, College of Fisheries, Ratnagiri, for the facilities provided during the research work. The authors are also grateful to the local fishers for their help and support in sampling during the entire study period.

\section{Authors' contributions}

URG conducted the research and drafted the paper. MSS provided overall supervision. RAP and ASP helped during sampling and provided lab facilities. VHN, SKC, and KKR analyzed the data by employing the FiSAT computer program. ST and TK helped during writing, and review and editing the manuscript. All authors read the complete manuscript and approved it for publication.

\section{Funding}

This work was not funded by any national or international agencies.

Availability of data and materials

Data is available on request.

\section{Declarations}

Ethics approval and consent to participate

Not applicable

Consent for publication

Not applicable

\section{Competing interests}

The authors declare that they have no competing interests.

\section{Author details}

${ }^{1}$ ICAR-Central Institute of Fisheries Education, Mumbai, Maharashtra 400061 , India. ${ }^{2}$ College of Fisheries, Shirgaon, Ratnagiri, Maharashtra 415 629, India.

${ }^{3}$ TNJFU-Fisheries College and Research Institute, Thoothukudi 628 008, India. ${ }^{4}$ ICAR-Central Marine Fisheries Research Institute, Veraval, Gujarat 362 269, India.

Received: 15 January 2021 Accepted: 27 April 2021

Published online: 08 May 2021

\section{References}

Abdussamad, E. M., Mini, K. G., Gireesh, R., Prakasan, D., Retheesh, T. B., Rohit, P., \& Gopalakrishnan, A. (2018). Systematics, fishery and biology of the white sardine Escualosa thoracata (Valenciennes, 1847) exploited off Kerala, southwest coast of India. Indian Journal of Fisheries, 65(1), 26-31. https://doi.org/1 0.21077/ijf.2018.65.1.69762-05.

Beverton, R. J. H., \& Holt, S. J. (1957). On the dynamics of exploited fish population. Fisheries Investigations, 11, 1-533. https://doi.org/10.1007/978-94011-2106-4_2.

Boiko, E. G. (1964). Prediction of reserves and catches of Azovlueiperca. In Trudy VNIRO, (p. 50).

CMFRI (2018). Annual report 2017-18. Technical report, (p. 304). Central Marine Fisheries Research Institute.

Cushing, D. H. (1968). Fisheries biology: a study in population dynamics, (p. 200). University of Wisconsin Press.

Devanesan, D. W., \& John, V. (1941). On the natural history of Kowala thoracata (Cuv. and Val.) with special reference to its gonads and eggs. Records of the Indian Museum, 43(2), 215-216.

Devaraj, M. (1983). Fish population dynamics: a course manual. CIFE Bulletin, 3(10), $83-89$.

Gosavi, S. M., Kharat, S. S., Kumkar, P., \& Tapkir, S. D. (2019). Assessing the sustainability of lepidophagous catfish, Pachypterus khavalchor (Kulkarni, 
1952), from a tropical river Panchaganga, Maharashtra, India. The Journal of Basic and Applied Zoology, 80(1), 1-10.

Gulland, J. A. (1971). The fish resource of the oceans, (p. 255). Fishing News Books Ltd.

Gurjar, U. R., Sawant, M. S., Pawar, R. A., Nirmale, V. H., \& Pawase, A. S. (2018), Reproductive biology and fishery of the white sardine, Escualosa thoracata (Valenciennes, 1847) from the Ratnagiri coast, Maharashtra. Indian Journal of Geo-Marine Sciences, 47(12), 2485-2491.

Gurjar, U. R., Sawant, M. S., Pawar, R. A., Nirmale, V. H., Pawase, A. S., \& Takar, S. (2017). A study on food and feeding habits of white sardine, Escualosa thoracata (Valenciennes, 1847) from the Ratnagiri coast, Maharashtra. Journal of Experimental Zoology India, 20(2), 755-762.

Gurjar, U. R., Sawant, M. S., Takar, S., Pawar, R. A., Nirmale, V. H., \& Pawase, A. S. (2017). Biometric analysis of white sardine, Escualosa thoracata (Valenciennes, 1847) along the Ratnagiri coast of Maharashtra, India. Journal of Experimental Zoology India, 20(2), 845-849.

Jones, R. (1982). Ecosystems, food chains and fish yields. In: Theory and management of tropical fisheries. ICLARM Conference Proceedings, 9 (360), 195-239.

Jones, R., \& Van Zalinge, N. P. (1981). Estimates of mortality rate and population size for shrimp in Kuwait waters. Kuwait Bulletin of Marine Science, 2, 273-288.

Kende, D. R., Nirmale, V. H., Gurjar, U. R., Qayoom, U., Syed, N., \& Pawar, R. A. (2020). Biometric analysis of moustached thryssa mystax (Bloch and Schneider, 1801) along the Ratnagiri coast of Maharashtra, India. Indian Journal of Fisheries, 67(2), 110-113. https://doi.org/10.21077/ijf.2019.67.2.82 889-15.

King, M. (1995). Fisheries biology, assessment and management, (pp. 158-160). Fishing News Books.

Krishnan, S., \& Mishra, S. (2004). An inventory of fish species described originally from fresh and coastal marine waters of Pondicherry. Records of the Zoological Survey of India, 102(3-4), 65-87.

Misra, K. S. (1947). A checklist of the fishes of India, Burma, and Ceylon. I. Elasmobranchii and Holocephalii. Records of the Indian Museum, 45, 1-46.

Mookerjee, H. K., \& Bhattacharya, R. (1950). Some aspects of the natural history of Clupea lile. In Proceedings of the 37th Indian Science Congress Pt. III, (p. 250).

Munro, J. L., \& Pauly, D. (1983). A simple method for comparing growth of fishes and invertebrates. ICLARM FishByte, 1(1), 5-6.

Nabi, M. R., Hoque, M. A., \& Rahman, M. M. (2009). Population dynamics of Escualosa thoracata from estuarine set bag net fishery of Bangladesh. Journal of Science and Technology, 7, 7-22.

Nair, R. V. (1952). Studies on the life history, bionomics and fishery of the white sardine, Kowala coval (Cuv.). In Proceedings of the Indo-Pacific Fisheries Council 1951, Sec.2, (p. 103).

Ogle, D. (2016). Introductory fisheries analyses with R. CRC Press.

Parra, I., Almodóvar, A., Nicola, G. G., \& Elvira, B. (2009). Latitudinal and altitudinal growth patterns of brown trout Salmo trutta at different spatial scales. Journal of Fish Biology, 74(10), 2355-2373. https://doi.org/10.1111/j.1095-864 9.2009.02249.x.

Patterson, K. (1992). Fisheries for small pelagic species: an empirical approach to management targets. Reviews in Fish Biology and Fisheries, 2(4), 321-338. https://doi.org/10.1007/BF00043521.

Pauly, D. (1980). On the inter-relationships between natural mortality, growth parameters and mean environmental temperatures in 175 fish stocks. ICES Journal of Marine Science, 39(2), 175-192. https://doi.org/10.1093/icesjms/3 9.2.175.

Pauly, D. (1983). Some simple methods for the assessment of tropical fish stocks. FAO Fisheries Technical Paper, 234, 1-52.

Pauly, D. (1984). Length converted catch curve, a powerful tool in fisheries research in the tropics (part-II). ICLARM FishByte, 2(1), 17-19.

Prajapat, P. S. (2015). A study on biology of white sardine, Escualosa thoracata (Valenciennes, 1847) along Goa coast of India, (p. 85). M.F.Sc. dissertation, C.I.F. E. (Deemed University).

Prasad, G., Ali, A., Harikrishnan, M., \& Raghavan, R. (2012). Population dynamics of an endemic and threatened yellow catfish, Horabagrus brachysoma (Günther) from River Periyar, Kerala, India. Journal of Threatened Taxa, 4(2), 2333-2342. https://doi.org/10.11609/JoTT.02590.2333-42.

Rahangdale, S., Chakraborty, S. K., Jaiswar, A. K., Shenoy, L., \& Raje, S. G. (2016). Preliminary study on growth and mortality of Escualosa thoracata (Valenciennes, 1847) from Mumbai waters. Indian Journal of Geo-Marine Sciences, 45, 290-295.
Raje, S. G., Deshmukh, V. D., \& Thakurdas (1994). Fishery and biology of white sardine, Escualosa thoracata (Valenciennes) at Versova, Bombay. Journal of the Indian Fisheries Association, 24, 51-62.

Ricker, W. E. (1975). Computation and interpretation of biological statistics of fish populations. Bulletin of Fisheries Research Board Canada, 191, 1-382.

Sekharan, K. V. (1962). On the oil sardine fishery of the Calicut area during the years 1955-56 to 1958-59. Indian Journal of Fisheries, 9(2), 679-700.

Shabir, A. D., Thomas, S. N., Chakraborty, S. K., \& Jaiswar, A. K. (2014). Lengthweight relationships for five species of Clupeidae caught from Mumbai coast. Fishery Technolgy, 51, 291-294.

Stéquert, B., Panfili, J., \& Dean, J. M. (1996). Age and growth of yellowfin tuna, Thunnus albacares, from the western Indian Ocean, based on otolith microstructure. Oceanographic Literature Review, 12(43), 1275.

Taiwo, O. (2010). Length frequency distribution and length-weight relationship of Schilbe mystus from Lekki Lagoon in Lagos, Nigeria. Journal of Agricultural and Veterinary Sciences, 2, 63-69.

Takar, S., \& Gurjar, U. R. (2020). Review on present status, issues and management of Indian marine fisheries. Innovative Farming, 5(1), 34-41.

von Bertalanffy, L. (1934). Untersuchungen Über die Gesetzlichkeit des Wachstums. W. Roux' Archiv f. Entwicklungsmechanik, 131(4), 613-652. https:// doi.org/10.1007/BF00650112.

von Bertalanffy, L. (1938). A quantitative theory of organic growth. Human Biology, 10, 181-213.

\section{Publisher's Note}

Springer Nature remains neutral with regard to jurisdictional claims in published maps and institutional affiliations.

\section{Submit your manuscript to a SpringerOpen ${ }^{\circ}$ journal and benefit from:}

- Convenient online submission

- Rigorous peer review

- Open access: articles freely available online

High visibility within the field

- Retaining the copyright to your article

Submit your next manuscript at $\boldsymbol{\nabla}$ springeropen.com 